\title{
Inhibition of inducible nitric oxide synthase in the human intestinal epithelial cell line, DLD-1, by the inducers of heme oxygenase 1, bismuth salts, heme, and nitric oxide donors
}

\author{
M Cavicchi, L Gibbs, B J R Whittle
}

\begin{abstract}
Background-The inducible isoform of nitric oxide synthase (iNOS) may be involved in the mucosal injury associated with inflammatory bowel disease (IBD). In contrast with iNOS, the inducible heme oxygenase 1 (HO-1) is considered to act as a protective antioxidant system.

Aims-To evaluate the effects of the known HO-1 inducers, cadmium and bismuth salts, heme, and nitric oxide (NO) donors, on iNOS activity, and expression in the human intestinal epithelial cell line DLD-1.
\end{abstract}

Methods-iNOS activity was assessed by the Griess reaction and the radiochemical L-arginine conversion assay. iNOS mRNA and iNOS protein expression were determined by northern and western blotting, respectively.

Results-Cytokine exposure led to induction of iNOS activity, iNOS mRNA, and iNOS protein expression. Preincubation of DLD-1 cells with heme (1-50 $\mu M)$ inhibited cytokine induced iNOS activity in a concentration dependent manner. This inhibitory effect was abolished by the HO-1 specific inhibitor tin protoporphyrin. Preincubation with NO donors sodium nitroprusside (SNP 1-1000 $\mu M$ ) or S-nitroso-acetyl-penicillamine (SNAP 1-1000 $\mu \mathrm{M})$, or with the heavy metals cadmium chloride (10-40 $\mu \mathrm{M})$, bismuth citrate, or ranitidine bismuth citrate (10$3000 \mu M)$ inhibited iNOS activity in a concentration dependent manner. Moreover, SNP and heme abolished cytokine induced iNOS protein as well as iNOS mRNA expression, whereas cadmium chloride did not modify iNOS protein expression.

Conclusions-Heme, the heavy metals cadmium and bismuth, as well as NO donors, are potent inhibitors of cytokine induced iNOS activity. Heme and NO donors act at the transcriptional level inhibiting iNOS mRNA expression. Such findings suggest the potential for interplay between the iNOS and HO-1 systems, which may modulate the progress of IBD. (Gut 2000;47:771-778)

Keywords: inducible nitric oxide synthase; nitric oxide; colonic epithelial cells; cytokines; heme oxygenase-1; bismuth citrate
The inducible isoform of nitric oxide synthase (iNOS; EC 1.14.13.39) can produce sustained high quantities of nitric oxide (NO). ${ }^{1}$ Expression of iNOS and concentrations of $\mathrm{NO}$ produced or its subsequent cytotoxic products such as peroxynitrite, formed from a combination of NO and superoxide, could play a key role in the pathogenesis of inflammatory bowel disease (IBD). Indeed, over expression of iNOS protein, ${ }^{2-4}$ increased iNOS activity or NO release, ${ }^{5-8}$ and increased iNOS mRNA levels ${ }^{9}$ have been demonstrated both in ulcerative colitis and Crohn's disease. The iNOS isoform is also expressed in human intestinal epithelial cell lines after exposure to proinflammatory stimuli such as cytokines. ${ }^{10}$

The NO pathway may also interact with other systems that may be involved in the modulation of IBD. One such system is heme oxygenase 1 (HO-1; EC 1.14.99.3), a microsomal inducible enzyme which converts heme into biliverdin, carbon monoxide, and free ferrous iron, biliverdin subsequently being reduced to bilirubin. ${ }^{11} \mathrm{HO}-1$ is considered to provide a potent antioxidant system leading to removal of heme, a promoter of lipid peroxidation and reactive oxygen intermediates formation. ${ }^{12}$ In addition, bile pigments resulting from HO-1 activity possess antioxidant and anticomplement properties. ${ }^{13} 14$ The associated induction of ferritin also provides antioxidant activity ${ }^{15}$ and, because to its ability to sequestrate free iron, limits the subsequent production of reactive oxygen intermediates via the Fenton reaction. ${ }^{17}{ }^{18}$ This $32 \mathrm{kDa}$ heat shock protein can be expressed in numerous cell types following a number of different stimuli, including endotoxin or cytokine stimulation, ${ }^{161920}$ heavy metals, ${ }^{21} \mathrm{NO}$ donors, ${ }^{22} 23$ or heme. ${ }^{2425}$

In recent studies, heme and salts of heavy metals such as cadmium or bismuth, as well as NO donors, have been shown to be potent inducers of $\mathrm{HO}-1$ in the human intestinal

Abbreviations used in this paper: iNOS, inducible nitric oxide synthase; NO, nitric oxide; IBD, inflammatory bowel disease; HO-1, heme oxygenase 1 ; DMEM, Dulbecco modified Eagle's medium; EDTA, ethylene diamine tetraacetic acid; PBS, phosphate buffered saline; TNF- $\alpha$, tumour necrosis factor $\alpha$; IL- $1 \beta$, interleukin $1 \beta$; IFN- $\gamma$, interferon $\gamma ; \beta$-NADPH, $\beta$-nicotinamide adenine dinucleotide phosphate; EGTA, ethylene glycol-bis tetraacetic acid; SDS, sodium dodecyl sulphate; SnPP, tin protoporphyrin; SNP, sodium nitroprusside; SNAP,

S-nitroso-acetyl-penicillamine. 
epithelial cell line DLD-1. ${ }^{26}{ }^{27}$ This cell line is also known to be capable of generating relatively high levels of $\mathrm{NO}$ through induction of iNOS after exposure to cytokines. ${ }^{10}{ }^{28}$ Using this cell line, the present study has investigated the potential interaction between the iNOS and HO-1 enzyme systems in intestinal epithelial cells and hence their possible involvement in the pathogenenesis of IBD. Thus the effects of the HO-1 inducers heme, NO donors, and salts of the heavy metals cadmium and bismuth on iNOS activity and on iNOS expression in DLD-1 cells, both at the protein and mRNA level, were investigated.

\section{Methods}

CELL CULTURE

The DLD-1 cell line was obtained from the European Collection of Cell Culture (Salisbury, UK) (No 90102540) and used between passages 25 and 50. Cells were grown in Dulbecco modified Eagle's medium (DMEM) with $4 \mathrm{mM}$ L-glutamine and $10 \%$ heat inactivated fetal calf serum. Cells were cultured at $37^{\circ} \mathrm{C}$ in a humidified atmosphere of $95 \%$ air and $5 \% \mathrm{CO}_{2}$, refed every two days and passaged weekly. Cells were allowed to grow for 72-96 hours to confluence before use.

CELL COUNTING AND PROTEIN CONCENTRATION Cells were harvested and dissociated in a solution of $0.25 \%$ trypsin and $3 \mathrm{mM}$ ethylene diamine tetraacetic acid (EDTA) in phosphate buffered saline (PBS) $\mathrm{pH} 7.4$ (without calcium and magnesium). After five minutes, cells were counted with a haemocytometer after adding trypan blue. Only cells that excluded dye were counted as viable cells. Results were expressed as number of viable cells per $\mathrm{ml}$. Protein concentration was determined using a modification of the Bradford method (Biorad kit) and bovine serum albumin as a standard. Results were expressed as $\mathrm{mg}$ of protein per $\mathrm{ml}$.

\section{CELL VIABILITY MEASUREMENT}

Mitochondrial respiration, an indicator of cell viability, was assessed by the mitochondrial dependent reduction of MTT [3-(4,5dimethylthiazol-2-yl)-2,5-diphenyltetrazolium bromide] to formazan. Cells grown in 96 well plates were incubated at $37^{\circ} \mathrm{C}$ for one hour with $0.4 \mathrm{mM}$ MTT. Cells were solubilised in $100 \mu \mathrm{l}$ dimethyl sulphoxide and absorbance was read at $\lambda=550 \mathrm{~nm}$. Results were expressed as percentage of control (non-treated cells).

\section{NOS ACTIVITY DETERMINED BY THE GRIESS}

REACTION

Cells were stimulated in 96 well plates by a cytokine combination with tumour necrosis factor $\alpha(\mathrm{TNF}-\alpha ; 100 \mathrm{ng} / \mathrm{ml})$, interleukin $1 \beta$ (IL- $1 \beta ; 5 \mathrm{ng} / \mathrm{ml}$ ) and interferon $\gamma($ IFN- $\gamma ; 200$ $\mathrm{U} / \mathrm{ml}$ ). After 24 hours, culture medium was removed for determination of nitrite production as an index of NOS activity. Medium (50 $\mu \mathrm{l})$ was transferred to a 96 well plate. Then, $50 \mu \mathrm{l}$ of Griess reagent $(0.25 \mathrm{M}$ phosphoric acid, $30 \mathrm{mM}$ sulphanilamide, $2 \mathrm{mM}$ naphthylethylene diamine) was added to each well. The resultant colour change was quantified by spectrophotometry $(\lambda=550-650 \mathrm{~nm})$. Nitrite levels were determined using a sodium nitrite standard curve and are expressed as $\mu \mathrm{M} / 10^{6}$ cells according to the cell number in each well. The limit of detection of nitrite using this assay was $1 \mu \mathrm{M}$, well below the level of production of nitrite by this cell line following iNOS induction under these conditions. ${ }^{28}$

NOS ACTIVITY DETERMINED BY THE L-ARGININE CONVERSION ASSAY

NOS activity was determined by quantifying conversion of radiolabelled L-arginine to citrulline using the method previously described by Tepperman and colleagues ${ }^{29}$ with some modifications. Cells were washed with ice cold PBS ( $\mathrm{pH}$ 7.4) and homogenised in $10 \mathrm{mM} \mathrm{N}$-[2hydroxyethyl] piperazine- $N$ '-[2-ethanesulphonic acid] (HEPES), $32 \mathrm{mM}$ sucrose, $1 \mathrm{mM}$ dithiotreitol, 0.1 EDTA, $10 \mu \mathrm{g} / \mathrm{ml}$ soybean trypsin inhibitor, $10 \mu \mathrm{g} / \mathrm{ml}$ leupeptin, and $2 \mu \mathrm{g} / \mathrm{ml}$ aprotinin. Homogenates were spun for 15 minutes at $21000 \mathrm{~g}$ at $4^{\circ} \mathrm{C}$. Samples $(50 \mu \mathrm{l})$ were incubated for 30 minutes at $37^{\circ} \mathrm{C}$ in $150 \mu \mathrm{l}$ of assay buffer $\left(50 \mathrm{mM} \mathrm{KH} \mathrm{PO}_{4}, 1 \mathrm{mM}\right.$ $\mathrm{MgCl}_{2}, 50 \mathrm{mM}$ L-valine, $0.2 \mathrm{mM} \mathrm{CaCl}_{2}, 3 \mu \mathrm{M}$ flavin adenine dinucleotide, $3 \mu \mathrm{M}$ flavin mononucleotide, $100 \mu \mathrm{M}$ tetrahydro-L-biopterin dihydrochloride, $300 \mu \mathrm{M} \beta$-nicotinamide adenine dinucleotide phosphate $(\beta-\mathrm{NADPH})$, $10 \mu \mathrm{M}$ L-arginine, and $2.1 \mathrm{pM}\left[{ }^{3} \mathrm{H}\right]-\mathrm{L}-$ argininemonohydrochloride). The reaction was terminated by addition of $1 \mathrm{ml}$ of $1: 1(\mathrm{v} / \mathrm{v})$ suspension of DOWEX $\left(\mathrm{Na}^{+}\right.$form) in distilled water. The mixture was resuspended by addition of $200 \mu \mathrm{l}$ of distilled water and allowed to settle for 30 minutes. Supernatant $(300 \mu \mathrm{l})$ was removed and radioactivity determined by scintillation counting. The effect of NO donors and bismuth salts on NOS activity was characterised by addition of these agents to the reaction mixture. Calcium dependency of NOS activity was determined by addition of ethylene glycol-bis ( $\beta$-aminoethyl ether) tetraacetic acid (EGTA; $1 \mathrm{mM}$ ). NOS activity was confirmed by inhibition by nitro-L-arginine $(500 \mu \mathrm{M})$. Inducible NOS was defined as citrulline formation inhibited by nitro-L-arginine but not inhibited by EGTA. Inducible NOS activity was expressed as $\mathrm{pmol} / \mathrm{min} / \mathrm{mg}$ protein.

\section{WESTERN BLOTTING}

Cells were washed with ice cold PBS ( $\mathrm{pH} 7.4$ ) and homogenised in Tris-mannitol buffer (2 $\mathrm{mM}$ Tris 7-9, $50 \mathrm{mM}$ mannitol, $100 \mu \mathrm{M}$ phenyl methyl sulphonyl fluoride, $2 \mu \mathrm{M}$ leupeptin, 0.5 $\mathrm{mu} / \mathrm{ml}$ aprotinin, and $0.5 \%$ Triton $\mathrm{X} 100$ ). Homogenates were sonicated twice for $10 \mathrm{sec}-$ onds on ice and spun for 15 minutes at $21000 \mathrm{~g}$ at $4^{\circ} \mathrm{C}$. Aliquots of $100 \mu \mathrm{g}$ of total cellular protein were denatured by mixing and boiling $\mathrm{v} / \mathrm{v}$ with $20 \mathrm{mM}$ Tris 7-9, $2 \mathrm{mM}$ EDTA, $2 \%$ sodium dodecyl sulphate (SDS), $10 \%$ $\beta$-mercaptoethanol, and $20 \%$ glycerol. Samples were electrophoresed on $7.5 \%$ SDSpolyacrylamide gel and transferred to nitrocellulose membranes (Amersham, Little Chalfont, UK). After blocking with PBS ( $\mathrm{pH}$ 7.4), $0.25 \%$ Tween $20(\mathrm{v} / \mathrm{v})$, and $5 \%$ non-fat dried milk, membranes were probed with anti- 
$\mathrm{CM} \mathrm{CM}$

$+\quad+$ Con $\mathrm{CM} \mathrm{CdCl}_{2}$ SNP FePP SNP FePP
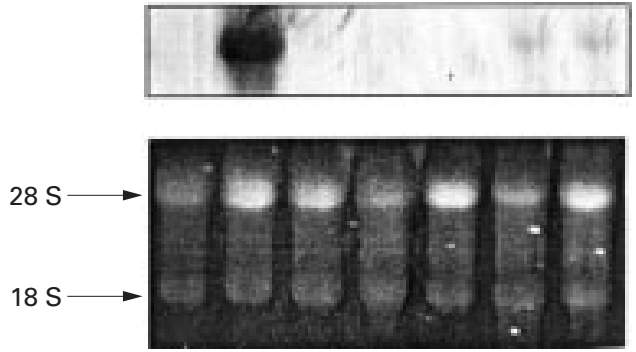

Figure 1 Effects of cadmium chloride, sodium nitroprusside, and heme on cytokine induced inducible nitric oxide synthase ( $i N O S$ ) $m R N A$ expression in DLD-1 cells. DLD-1 cells were treated for six hours with vehicle alone (Con), cytomix (CM; TNF-a $100 \mathrm{ng} / \mathrm{ml}, \mathrm{IL}-1 \beta$ $5 \mathrm{ng} / \mathrm{ml}, \mathrm{IFN}-\gamma 200 \mathrm{U} / \mathrm{ml})$, cadmium chloride ( $\mathrm{CdCl}_{2}$ $10 \mu \mathrm{M})$, sodium nitroprusside (SNP $10 \mathrm{mM}$ ), heme (FePP $50 \mu M), C M+S N P(10 \mathrm{mM}$, six hours pretreatment), and $C M+F e P P(50 \mu M$, six hours pretreatment). iNOS $m R N A$ expression was assessed by northern blot after standard RNA extraction. The top panel is the northern blot and the bottom panel is ethidium bromide staining of $28 S$ and $18 S R N A$ bands indicating loading of the lanes. This is a representative of three experiments.

iNOS polyclonal antibody (1/500) (Autogen Bioclear, Calne, UK) for one hour at room temperature, washed with PBS-Tween 20, and incubated with horseradish peroxidaseconjugated second antibody (1/4000) for one hour at room temperature. Membranes were developed using a enhanced chemiluminescence system (Amersham) and exposed to Hyperfilm (Amersham). Films were analysed using the Molecular Analyst Software (BioRad Laboratories, Hercules, USA) after scanning on a densitometer (GS-700 Imaging Densitometer, BioRad Laboratories).

\section{NORTHERN BLOTTING}

The iNOS cDNA probe was obtained by polymerase chain reaction amplification of iNOS RNA from cytokine induced DLD-1 cells. The following primers were used to amplify the 3590-3848 bp region of human iNOS cDNA according to the published sequence (GenBank accession number: L09210), leading to a 259 bp fragment: 5'CGG TGC TGT ATT TCC TTA CGA GGC GAA GAA GG and 5'- GGT GCT GCT TGT TAG GAG GTC AAG TAA AGG GC. Then, the positive band was excised from the agarose gel and cDNA purified using a commercially available kit (Geneclean kit, Bio 101 Inc., La Jolla, California, USA).

Total RNA from cell monolayers was extracted using Trizol (Gibco BRL, Paisley, UK).

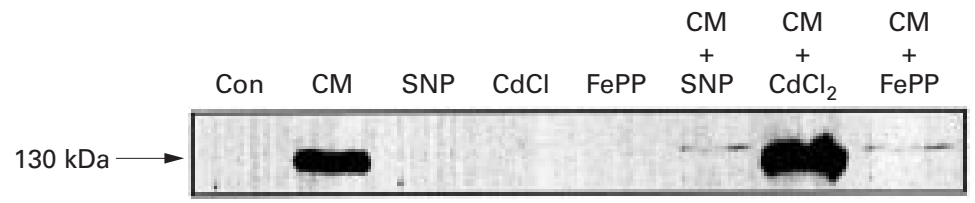

Figure 2 Effects of cadmium chloride, sodium nitroprusside, and heme on cytokine induced inducible nitric oxide synthase ( $i N O S$ ) protein expression in DLD-1 cells. DLD-1 cells were treated for 12 hours with vehicle alone (Con), cytomix (CM; TNF-a $100 \mathrm{ng} / \mathrm{ml}$,

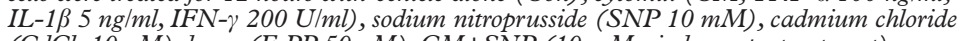
$(\mathrm{CdCl}, 10 \mu \mathrm{M})$, heme (FePP $50 \mu \mathrm{M}), \mathrm{CM}+\mathrm{SNP}(10 \mathrm{mM}$, six hours pretreatment), $\mathrm{CM}+\mathrm{CdCl}_{2}(10 \mu \mathrm{M}$, six hours pretreatment), and $\mathrm{CM}$ and $\mathrm{FePP}(50 \mu \mathrm{M}$, six hours pretreatment). iNOS protein expression was determined by western blot analysis using a monoclonal iNOS antibody. This is a representative of three different experiments.
The amount of RNA was calculated from optical density measurements at $\lambda=260 \mathrm{~nm}$. Total RNA $(10 \mu \mathrm{g})$ were loaded on a $1 \%$ denaturing agarose gel containing $2 \mathrm{M}$ formaldehyde and $6 \mathrm{mM}$ 3(N-morpholino)propanesulphonic acid. RNA was transferred onto an uncharged nylon membrane followed by hybridisation (Stratagene QuikHyb hybridisation solution, Cambridge, UK). The iNOS cDNA was radiolabelled with $\left[{ }^{32} \mathrm{P}\right] \mathrm{dCTP}$ using the random primer method (Multiprime DNA labelling system, Amersham). A photograph of agarose gel stained with ethidium bromide was taken as a control of equivalent loading between lanes. Films were analysed as described for western blotting.

STATISTICAL ANALYSIS

Data are shown as mean (SEM) from at least three independent experiments, each conducted in triplicate. Northern and western blots are shown as representative photographs of three independent experiments. Statistical significance was assessed by Student's $t$ test where $\mathrm{p}<0.05$ was taken as significant.

\section{MATERIALS}

The iNOS antibody was from Santa Cruz Biotechnology (Autogen Bioclear, Calne, UK). Human TNF- $\alpha$ was from R\&D Systems (Abingdon, UK). Nitrate reductase was from Boehringer Mannheim (Lewes, UK). Methanol and ethanol were from BDH Laboratories Supplies (Lutterworth, UK). Bis-acrylamide solution and protein assay kit were from Bio-Rad Laboratories (Hertfordshire, UK). DMEM, non-essential amino acids, Trizol, and primers were obtained from Gibco BRL (Paisley, UK). Tetrahydro-L-biopterin dihydrochloride was purchased from CalbiochemNovabiochem Corp (La Jolla, USA). $\left[{ }^{3} \mathrm{H}\right]-\mathrm{L}-$ arginine monohydrochloride was obtained from Amersham International (Little Chalfont, UK). 1400W ( $N$-(3-(aminomethyl) benzyl)acetamidine) and ranitidine bismuth citrate were kind gifts from GlaxoWellcome Stevenage, and Stockley Park, UK. All other compounds and chemicals were purchased from Sigma (Poole, UK).

\section{Results}

EFFECTS OF CYTOKINE EXPOSURE ON NITRITE PRODUCTION AND INOS EXPRESSION

No iNOS mRNA or protein was detected in control unstimulated DLD-1 cells, as shown by northern and western blots, respectively. Similarly, unstimulated DLD-1 cells produced very low levels of $\mathrm{NO}_{2}^{-}\left(0.9(0.5) \mu \mathrm{M} / 10^{6}\right.$ cells $/ 24$ hours). Incubation with a combination of IL-1 $\beta$ (5 ng/ml), TNF- $\alpha$ (100 ng/ml), and IFN- $\gamma(200 \mathrm{U} / \mathrm{ml})$ (cytomix) caused iNOS mRNA expression determined by northern blot after six hours (fig 1). This was followed by iNOS protein expression at 12 hours, as shown by western blot (fig 2), and an increase in NOS activity, as determined by $\mathrm{NO}_{2}{ }^{-}$release in the cell supernatant which reached 95.1 (6.5) $\mu \mathrm{M} / 10^{6}$ cells after 24 hours exposure to these cytokines. 

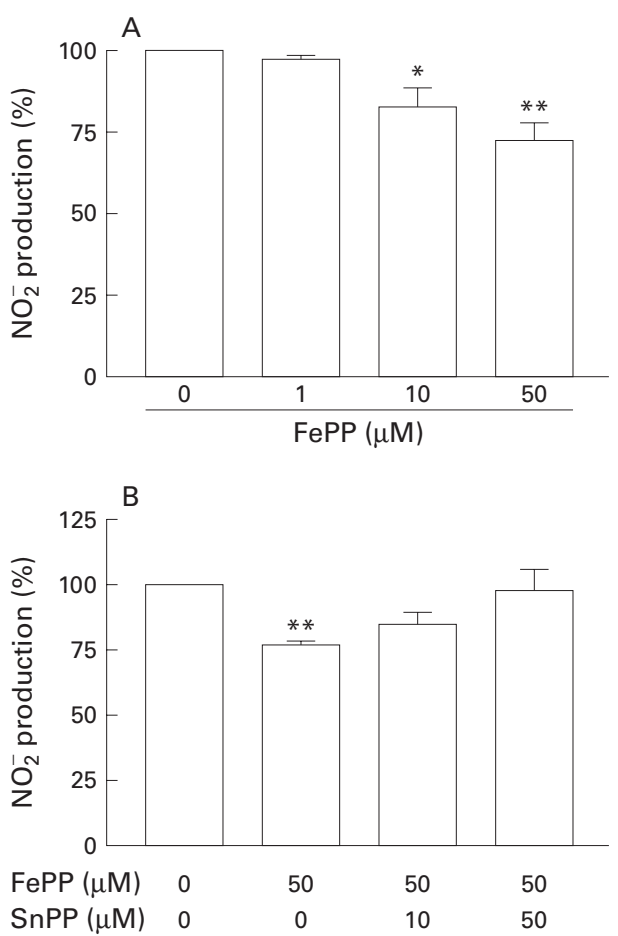

Figure 3 Effects of heme on cytokine induced $\mathrm{NO}_{2}$ production and reversal by the $\mathrm{HO}-1$ inhibitor tin protoporphyrin. (A) DLD-1 cells were pretreated in serum free medium for six hours with increasing concentrations of heme $(\mathrm{FePP} 1-50 \mu \mathrm{M})$ and then for 24 hours with cytomix (TNF-a $100 \mathrm{ng} / \mathrm{ml}, \mathrm{IL}-1 \beta 5 \mathrm{ng} / \mathrm{ml}, \mathrm{IFN}-\gamma 200 \mathrm{U} / \mathrm{ml})$. $\mathrm{NO}_{2}^{-}$levels were determined in the supernatant by the Griess reaction. Results are expressed as percentage of maximal induction (without $\mathrm{FePP}$ ) and represent mean (SEM) from three different experiments, each performed in triplicate. ${ }^{*}<<0.05, * \star x<0.01$ compared with maximal induction. (B) DLD-1 cells were pretreated in serum free medium for six hours with heme ( $\mathrm{FePP} 50 \mu \mathrm{M}$ ) and increasing concentrations of tin protoporhyrin (SnPP 10-50 $\mathrm{\mu M}$ ) and then for 24 hours with cytomix (TNF-a $100 \mathrm{ng} / \mathrm{ml}, \mathrm{IL}-1 \beta 5 \mathrm{ng} / \mathrm{ml}, \mathrm{IFN}-\gamma 200 \mathrm{U} / \mathrm{ml})$. NO- levels were determined in the supernatant by the Griess reaction. Results are expressed as percentage of maximal induction (without FePP or SnPP) and represent mean (SEM) from three different experiments, each performed in triplicate. $\star^{*} p<0.01$ compared with maximal induction.

This activity was due to iNOS as the highly selective iNOS inhibitor ${ }^{28}$ 1400W (10-1000 $\mu \mathrm{M})$ inhibited cytomix induced NOS activity with an $\mathrm{IC}_{50}$ of $7.6(1.2) \mu \mathrm{M}$. NOS enzyme activity was also directly assessed by the radiolabelled L-arginine conversion enzyme assay on the crude enzyme and in a cell free system prepared from DLD-1 cells. This confirmed induction of EGTA insensitive NOS after 24 hours exposure to cytomix, with an activity of $683(54) \mathrm{pmol} / \mathrm{min} / \mathrm{mg}$ protein. This activity was inhibited by incubation with $1400 \mathrm{~W}$, with an $\mathrm{IC}_{50}$ of $0.3(0.05) \mu \mathrm{M}(\mathrm{n}=3)$.

EFFECT OF CADMIUM CHLORIDE, HEME, OR SODIUM NITROPRUSSIDE (SNP) ON BASAL NITRITE PRODUCTION AND INOS EXPRESSION

Incubation with $\mathrm{HO}-1$ inducers cadmium chloride $\left(\mathrm{CdCl}_{2} \quad 10-40 \mu \mathrm{M}\right)$ or heme $(1-50$ $\mu \mathrm{M})$ did not stimulate iNOS activity, with $\mathrm{NO}_{2}^{-}$production $(1.25(0.3)$ and $2.2(0.2)$ $\mu \mathrm{M} / 10^{6} / 24$ hours with $\mathrm{CdCl}_{2} 40 \mu \mathrm{M}$ and heme $50 \mu \mathrm{M}$, respectively) not significantly different from that in control DLD-1 cells. Similarly, neither iNOS mRNA nor protein was induced

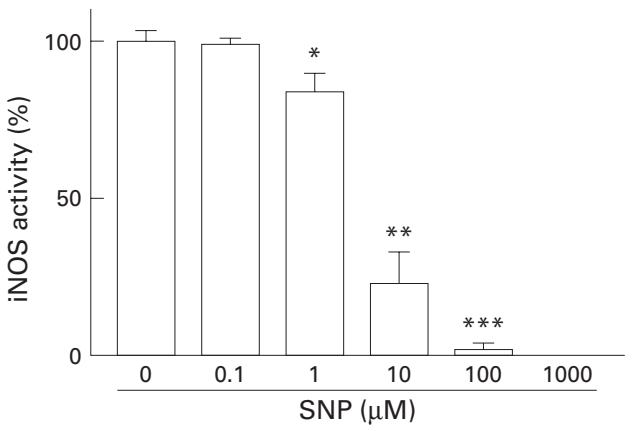

Figure 4 Effects of sodium nitroprusside on cytokine induced inducible nitric oxide synthase (iNOS) activity. The crude iNOS enzyme was isolated from homogenates of DLD-1 cells treated for 24 hours with cytomix (TNF- $\alpha$ $100 \mathrm{ng} / \mathrm{ml}, \mathrm{IL}-1 \beta 5 \mathrm{ng} / \mathrm{ml}, \mathrm{IFN}-\gamma 200 \mathrm{U} / \mathrm{ml})$. iNOS activity was determined by conversion of radiolabelled L-arginine to citrulline after incubation with the $\mathrm{NO}$ donor sodium nitroprusside (SNP 0.1-1000 $\mu \mathrm{M}$ ). Results are expressed as percentage of maximal induction (without SNP) and represent mean (SEM) from three different experiments, each performed in triplicate.

${ }^{*_{p}}<0.05,{ }^{\star *} p<0.01,{ }^{\star \star *} p<0.001$ compared with maximal induction.

by $\mathrm{CdCl}_{2}(10 \mu \mathrm{M})$, heme $(50 \mu \mathrm{M})$, or the NO donor SNP (10 mM), as shown in figs 1 and 2 .

EFFECT OF HEME ON CYTOKINE INDUCED INOS ACTIVITY

Preincubation of DLD-1 cells for six hours with heme $(1-50 \mu \mathrm{M})$ significantly and dose dependently inhibited increased NOS activity caused by cytokine exposure, as determined by the Griess reaction (fig 3A). The decrease in cytokine induced $\mathrm{NO}_{2}^{-}$production caused by heme $(50 \mu \mathrm{M})$ was dose dependently reversed by the specific HO-1 inhibitor tin protoporphyrin (SnPP 1-50 $\mu \mathrm{M}$ ), as shown in fig 3B.

EFFECT OF NO DONORS ON CYTOKINE INDUCED iNOS ACTIVITY

As the NO donors can themselves release $\mathrm{NO}_{2}{ }^{-}$, this would interfere with estimation of nitrite production by DLD-1 cells. Thus when incubated for three hours in DMEM without cells, SNP $10 \mathrm{mM}$ released 71.3 (6.7) $\mu \mathrm{M}$ of $\mathrm{NO}_{2}{ }^{-}$into the medium. Therefore, to assess the effects of NO donors on iNOS activity, the L-arginine conversion assay was performed utilising the crude iNOS enzyme isolated from homogenates of cytokine treated DLD-1 cells. In this cell free system, the NO donors SNP $\left(\begin{array}{ll}1-1000 & \mu \mathrm{M}\end{array}\right)$ and S-nitroso-acetylpenicillamine (SNAP 1-1000 $\mu \mathrm{M}$ ) also dose dependently inhibited iNOS activity with $\mathrm{IC}_{50}$ values of 5.2 (1.9) $\mu \mathrm{M}$ (fig 4) and 840 (140) $\mu \mathrm{M}$, respectively.

EFFECT OF CADMIUM CHLORIDE AND BISMUTH SALTS ON CYTOKINE INDUCED iNOS ACTIVITY Preincubation of DLD-1 cells for six hours with $\mathrm{CdCl}_{2}(10-40 \mu \mathrm{M})$ significantly and dose dependently inhibited the increased NOS activity caused by cytokine exposure, as determined by the Griess reaction (fig $5 \mathrm{~A}$ ).

Preincubation for six hours with bismuth citrate $(10-1000 \mu \mathrm{M})$ similarly resulted in a significant and concentration dependent decrease in cytokine induced $\mathrm{NO}_{2}^{-}$production with an $\mathrm{IC}_{50}$ of $1.03(0.3) \mathrm{mM}$ (fig 5B). In 

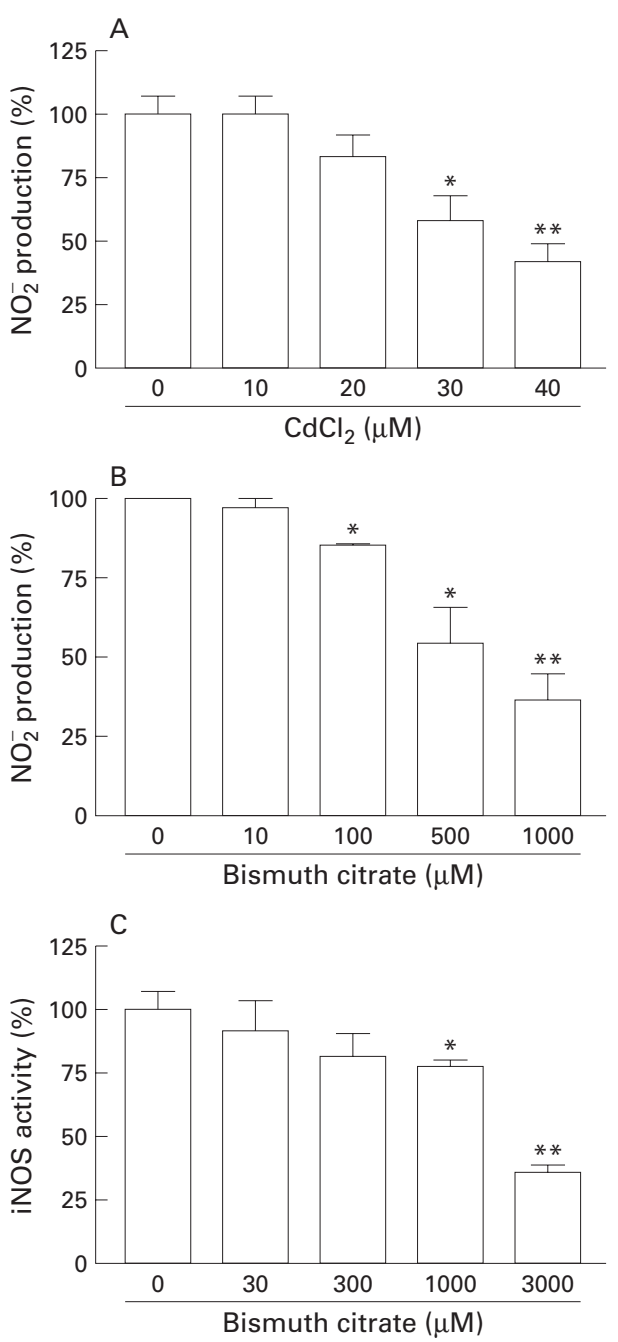

Figure 5 Effects of cadmium chloride and bismuth citrate on cytokine induced inducible nitric oxide synthase (iNOS) activity. $(A, B) . D L D-1$ cells were pretreated in serum free medium for six hours with increasing concentrations of cadmium chloride ( $\left.\mathrm{CdCl}_{2} 10-40 \mu \mathrm{M}\right)$ (A) or increasing concentrations of bismuth citrate $(30-1000 \mu M)(B)$ and then for 24 hours with cytomix (TNF-a $100 \mathrm{ng} / \mathrm{ml}, \mathrm{IL}-1 \beta$ $5 \mathrm{ng} / \mathrm{ml}, \mathrm{IFN}-\gamma 200 \mathrm{U} / \mathrm{ml}$ ). $\mathrm{NO}_{2}^{-}$levels were determined in supernatant by the Griess reaction. Results are expressed as percentage of maximal induction (without $\mathrm{CdCl}$ ) and represent mean (SEM) from three different experiments, each performed in triplicate. ${ }^{*} p<0.05,{ }^{*} p<0.01$ compared with maximal induction. (C) The crude $i$ NOS enzyme was isolated from homogenates of DLD-1 cells treated for 24 hours with cytomix (TNF-a $100 \mathrm{ng} / \mathrm{ml}, \mathrm{IL}-1 \beta 5 \mathrm{ng} / \mathrm{ml}$,

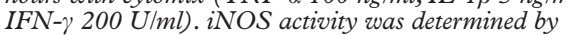
quantifying the conversion of radiolabelled L-arginine to citrulline after incubation with bismuth citrate (10-1000 $\mu M)$. Results are expressed as percentage of maximal induction (without bismuth citrate) and represent mean (SEM) from three different experiments, each performed in triplicate. ${ }^{*} p<0.05,{ }^{* *} p<0.01$ compared with maximal induction.

addition, bismuth citrate $(10-3000 \mu \mathrm{M})$ inhibited iNOS enzyme activity determined in the crude enzyme preparation by the L-arginine conversion assay with an $\mathrm{IC}_{50}$ of $2.1(0.5) \mathrm{mM}$ (fig 5C).

Additional studies were conducted with the more soluble form ranitidine bismuth citrate. ${ }^{30}$ Incubation of DLD-1 cells with ranitidine bismuth citrate $(10-3000 \mu \mathrm{M})$ caused a concentration dependent reduction in $\mathrm{NO}_{2}^{-}$production with an $\mathrm{IC}_{50}$ of $0.65(0.03) \mathrm{mM}(\mathrm{n}=4)$. Incubation of the crude enzyme preparation with ranitidine bismuth citrate also inhibited iNOS enzyme activity with an $\mathrm{IC}_{50}$ of 0.75 (0.07) $\mathrm{mM}(\mathrm{n}=4)$.

INHIBITION OF iNOS BY HEME OR SODIUM NITROPRUSSIDE INVOLVES DIFFERENT MECHANISMS

Preincubation for six hours with SNP $(10 \mathrm{mM})$ or heme $(50 \mu \mathrm{M})$ abolished cytokine induced iNOS protein expression as shown by western blot (fig 2). In contrast, $\mathrm{CdCl}_{2}(10 \mu \mathrm{M})$ did not modify iNOS protein expression after cytokine exposure (fig 2). Moreover, SNP (10 mM) and heme $(50 \mu \mathrm{M})$ substantially decreased iNOS mRNA expression induced by cytomix (fig 1 ), as determined by northern blot, when incubated six hours prior to stimulation with these cytokines.

EFFECTS ON CELL VIABILITY

Cell viability, as assessed by the MTT assay, was not significantly ( $p>0.05)$ affected by incubation for up to 24 hours with SNP (1 $\mathrm{mM}), \mathrm{SNAP}(5 \mathrm{mM}), \mathrm{CdCl}_{2}(10 \mu \mathrm{M})$, bismuth citrate $(1 \mathrm{mM})$, or heme $(50 \mu \mathrm{M})$. Incubation of cells with SNP (10 mM) for six hours did not significantly modify cell viability (98 (8)\% of the control cells) but was reduced after 24 hours incubation by $22(5) \%(\mathrm{p}<0.01)$.

\section{Discussion}

Study of the interactions between the two inducible enzyme systems $\mathrm{HO}-1$ and iNOS in intestinal epithelial cells may be of importance in understanding the pathophysiology of IBD as iNOS is recognised as a potential pathogenic factor in $\mathrm{IBD}^{31}$ while $\mathrm{HO}-1$ provides an antioxidant defensive system. In the present study, three different classes of compounds that are known to induce HO-1 (namely, heme, NO donors, and heavy metals) were shown to decrease cytokine induced iNOS activity or expression in the human intestinal epithelial cell line DLD-1. Two earlier studies have also suggested such inhibition of iNOS activity and iNOS protein expression in murine macrophages $^{32}$ or iNOS mRNA expression in lipopolysaccharide challenged rats $^{33}$ in association with $\mathrm{HO}-1$ induction.

The current work demonstrates that the HO-1 inducer heme can decrease iNOS mRNA and iNOS protein expression, as shown by northern and western analyses with a subsequent decrease in iNOS activity, as shown by the Griess reaction. Reversal of the inhibitory effect of heme on iNOS activity by the HO-1 inhibitor $\mathrm{SnPP}^{11}$ strongly suggests $\mathrm{HO}-1$ involvement in iNOS inhibition by heme. The mechanisms participating in this inhibition are, however, unclear. In DLD-1 cells, induction of the iNOS gene is thought to involve several transcription factors, including nuclear factor $\kappa \mathrm{B}, \mathrm{AP}-1$, and STAT- $1 \alpha .^{1034}$ Interestingly, $\mathrm{AP}-1$ and nucleur factor $\kappa \mathrm{B}$ binding sites have also been described in the promoter sequence of human HO-1..$^{35}$ It has recently been suggested that the AP-1 transcription factor would be a negative transcriptional regulator of iNOS in DLD-1 cells. ${ }^{34}$ Therefore, it is possible that prior $\mathrm{AP}-1$ activation by $\mathrm{HO}-1$ inducers 
such as heme may limit further cytokine induced iNOS expression. In addition, free iron, released during heme conversion by $\mathrm{HO}-1$, is capable of decreasing the transcription rate of the iNOS gene in murine macrophages. ${ }^{37}$

The heavy metals cadmium chloride and the bismuth salts, which are potent HO-1 inducers in these DLD-1 cells, ${ }^{26} 27$ dose dependently inhibited cytokine induced iNOS activity. In contrast with heme, cadmium did not modify iNOS protein expression indicating an effect on iNOS activity either through $\mathrm{HO}-1$ induction or by direct interaction between iNOS enzyme and the heavy metals. It is noteworthy that virtually all stimuli that induce $\mathrm{HO}$ can decrease cytochrome P450-like proteins, including iNOS. ${ }^{11}$ Heme oxygenase activation can also affect the amount of available heme, which is a necessary cofactor for full NOS activity. In addition, as both enzymes require NADPH, HO-1 induction prior to iNOS induction could limit the cellular concentration of this cofactor. The end products of HO-1 activation may also participate in iNOS inhibition, carbon monoxide being able to bind to and therefore inactivate the NOS enzyme. ${ }^{38} 39$

Inhibition of iNOS enzyme activity, as determined by the L-arginine conversion assay in a cell free system by bismuth citrate as well as the more soluble complex ranitidine bismuth citrate, ${ }^{30}$ suggests that this heavy metal can directly inhibit iNOS activity. As in the current study, cadmium has previously been shown to inhibit NOS activity without modifying protein levels in murine macrophages ${ }^{40}$ and recently, cadmium has been shown to inhibit brain NOS activity in rats. ${ }^{41}$ This effect could be related to binding to the haemoprotein domain of iNOS, blocking its activity, as suggested for other metals. ${ }^{42}{ }^{43}$ Due to the haemoprotein nature of iNOS, the latter could also be denatured on exposure to free radical production. Such conditions can occur after cadmium exposure which can lead to hydroxyl radicals ${ }^{44}$ and superoxide anion production. ${ }^{45}$ It is feasible that the heavy metal bismuth can inhibit iNOS activity through a similar mechanism. These findings may be of some relevance to the understanding of the mechanism of action underlying the therapeutic benefit of bismuth containing preparations in Helicobacter pylori gastric disease $\mathrm{e}^{46} 47$ in which increased iNOS expression has been shown. ${ }^{49}$ Moreover, such actions could contribute to the beneficial effects of bismuth containing preparations in the treatment of IBD..$^{50}$

The NO donor SNP inhibited iNOS transcription as shown by northern and western analyses but was also a potent inhibitor of iNOS activity as demonstrated by the L-arginine conversion assay. Another chemically unrelated NO donor SNAP inhibited epithelial cell iNOS activity. Previous studies have demonstrated direct NOS inhibition by $\mathrm{NO}^{51}$ as well as inhibition of iNOS gene transcription through modulation of nuclear factor $\kappa \mathrm{B} / \mathrm{I} \kappa \mathrm{B}$ pathways by $\mathrm{NO}$ in other non-epithelial cell types..$^{52-54}$
HO- 1 is considered a major antioxidant system, leading to a decrease in heme, which is a pro-oxidant molecule, ${ }^{12}$ in conjunction with an increase in biliverdin and bilirubin which possess anticomplement ${ }^{14}$ and antioxidant properties $^{13}$ and limit lipid peroxidation. ${ }^{55} \mathrm{HO}-1$ has also been found to modulate inflammation in vivo in a murine model of pleurisy, ${ }^{56}$ in an animal model of toxic nephritis, ${ }^{57}$ in ischaemiareperfusion lesions, ${ }^{58}$ as well as in endotoxic shock. ${ }^{33} 59$ Induction of HO-1 can also attenuate venular leucocyte adhesion provoked by pro-oxidant stimuli or inhibition of constitutive NO synthesis. ${ }^{60}$ Moreover, preliminary reports suggest that HO-1 can modulate experimental colitis in rats, ${ }^{61}$ and that $\mathrm{HO}-1$ is expressed in colonic crypt or superficial epithelium in IBD patients, as assessed by immunohistochemical techniques. ${ }^{62}$ The effect of endogenous HO-1 inducers on iNOS expression or activity observed in this study provides another mechanism by which the HO-1 system could be beneficial in inflammatory conditions. Indeed, ulcerative colitis and Crohn's disease have been shown to be associated with epithelial iNOS induction. ${ }^{236}$ This production of NO together with formation of reactive oxygen species ${ }^{63-66}$ can provoke epithelial cell injury through a process involving NO, peroxynitrite, and reactive nitrogen species. ${ }^{28}$

The present study using the DLD-1 cell line thus demonstrates that three different classes of HO-1 inducers are also potent inhibitors of iNOS transcription and/or activity in human intestinal epithelial cells and the findings suggest that these inhibitory actions may be mediated, at least partly, by HO-1 activation. While cadmium inhibits only iNOS activity without affecting iNOS protein expression, heme and the NO donor SNP substantially reduce iNOS mRNA expression and therefore protein expression. In addition, the use of a cell free enzyme system from these cells indicates that SNP and bismuth salts can directly inhibit iNOS enzymatic activity. Such findings suggest the potential for interplay between the iNOS and $\mathrm{HO}-1$ inducible enzyme systems. A primary response of intestinal epithelial cells in IBD may involve iNOS induction following pro-inflammatory cytokine release, with epithelial injury due to NO, reactive oxygen intermediates, and peroxynitrite. Subsequent feedback HO-1 induction by high levels of NO would permit the deactivation and clearance of reactive oxygen intermediates, as well as a subsequent decrease in NO through iNOS inhibition, which would therefore limit cytotoxicity.

The authors are indebted to Ms Elizabeth Wood for preparing the cultured cells, and to Ms Gayle Streeton for technical support. MC is a recipient of a from Institut de Recherche port. MC is a recipient of a grant from Institut de Recherche pour les Maladies de l'Appareil Digestif, France. Part of this work was supported by a grant from GlaxoWellcome, Stockley Park West, Uxbridge, UK.

1 Knowles RG, Moncada S. Nitric oxide synthases in mammals. Biochem ₹ 1994;298:249-58.

2 Singer II, Kawka DW, Scott S, et al. Expression of inducible nitric oxide synthase and nitrotyrosine in colonic epithelium in inflammatory bowel disease. Gastroenterology 1996; 111:871-85. 
3 Ikeda I, Kasajima T, Ishiyama S, et al. Distribution of inducible nitric oxide synthase in ulcerative colitis. $A m \mathcal{F}$

4 Godkin AJ, De Belder AJ, Villa L, et al. Expression of nitric oxide synthase in ulcerative colitis. Eur $\mathcal{F}$ Clin Invest 1996;26:867-72.

5 Boughton-Smith NK, Evans SM, Hawkey CJ, et al. Nitric oxide synthase activity in ulcerative colitis and Crohn's disease. Lancet 1993;342:338-40.

6 Kimura H, Miura S, Shigematsu T, et al. Increased nitric oxide production and inducible nitric oxide synthase activity in colonic mucosa of patients with active ulcerative coliity in colonic mucosa of patients with active ulcerative
tis and Crohn's disease. Dig Dis Sci 1997;42:1047-54.

7 Oudkerk Pool M, Bouma G, Visser JJ, et al. Serum nitrate levels in ulcerative colitis and Crohn's disease. Scand $\mathcal{f}$ Gastroenterol 1995;30:784-8.

8 Rachmilewitz D, Stamler JS, Bachwich D, et al. Enhanced colonic nitric oxide generation and nitric oxide synthase activity in ulcerative colitis and Crohn's disease. Gut 1995; 36:718-23.

9 McLaughlan JM, Seth R, Vautier G, et al. Interleukin-8 and inducible nitric oxide synthase mRNA levels in inflammatory bowel disease at first presentation. F Pathol 1997;181: $87-92$.

10 Salzman A, Denenberg AG, Ueta I, et al. Induction and activity of nitric oxide synthase in cultured human intestinal epithelial monolayers. Am f Physiol 1996;270:G565-73.

11 Maines MD. The heme oxygenase system: a regulator of second messenger gases. Annu Rev Pharmacol Toxicol 1997; second messen

12 Applegate LA, Luscher P, Tyrrell RM. Induction of heme oxygenase: a general response to oxidant stress in cultured mammalian cells. Cancer Res 1991;51:974-8.

13 Stocker R, Yamamoto Y, McDonagh AF, et al. Bilirubin is an antioxidant of possible physiological importance. Science 1987;235:1043-6.

14 Nakagami T, Toyomura K, Kinoshita $\mathrm{T}$, et al. A beneficial role of bile pigments as an endogenous tissue protector: anti-complement effects of biliverdin and conjugated bilirubin. Biochim Biophys Acta 1993;1158:189-93.

15 Vogt BA, Alam J, Croatt AJ, et al. Acquired resistance to acute oxidative stress. Possible role of heme oxygenase and ferritin. Lab Invest 1995;72:474-83.

16 Carraway MS, Ghio AJ, Taylor JL, et al. Induction of ferritin and heme oxygenase- 1 by endotoxin in the lung. Am $\mathcal{F}$ Physiol 1998;275:L583-92.

17 Cairo G, Tacchini L, Pogliaghi G, et al. Induction of ferritin synthesis by oxidative stress. Transcriptional and posttranscriptional regulation by expansion of the "free" iron pool. F Biol Chem 1995;270:700-3.

18 Halliwell B, Gutteridge JM. Oxygen free radicals and iron in relation to biology and medicine: some problems and concepts. Arch Biochem Biophys 1986;246:501-14.

19 Cantoni L, Rossi C, Rizzardini M, et al. Interleukin-1 and tumour necrosis factor induce hepatic haem oxygenase. Feedback regulation by glucocorticoids. Biochem $\mathcal{F} 1991$ 279:891-4.

20 Terry CM, Clikeman JA, Hoidal JR, et al. Effect of tumor necrosis factor-alpha and interleukin-1 alpha on heme oxygenase-1 expression in human endothelial cells. $A m \mathcal{F}$ Physiol 1998;274:H883-91

21 Maines MD, Kappas A. Metals as regulators of heme metabolism. Science 1977;198:1215-21.

22 Durante W, Kroll MH, Christodoulides N, et al. Nitric oxide induces heme oxygenase- 1 gene expression and carbon monoxide production in vascular smooth muscle cells. Circ Res 1997;80:557-64.

23 Vesely MJ, Exon DJ, Clark JE, et al. Heme oxygenase-1 induction in skeletal muscle cells: hemin and sodium nitroprusside are regulators in vitro. Am $\mathcal{F}$ Physiol 1998;275: prusside are

24 Tenhunen R, Marver HS, Schmid R. The enzymatic catabolism of hemoglobin: stimulation of microsomal heme oxygenase by hemin. F Lab Clin Med 1970;75:410-21.

25 Shibahara S, Yoshida T, Kikuchi G. Induction of heme oxygenase by hemin in cultured pig alveolar macrophages. Arch Biochem Biophys 1978;188:243-50.

26 Cavicchi M, Gibbs L, Whittle BJR. Inhibition of inducible nitric oxide synthase (iNOS) and induction of heme oxygenase- 1 by bismuth preparations in human intestinal epithelial cells. Gastroenterology 2000;118:A797.

27 Cavicchi M, Gibbs L, Whittle BJ. Induction of heme oxygenase-1 (HO-1) in human intestinal epithelial cells by nitric oxide donors. Gastroenterology 1999;116:A867.

28 Cavicchi M, Whittle BJ. Potentiation of cytokine induced iNOS expression in the human intestinal epithelial cell line,
DLD-1, by cyclic AMP. Gut 1999;45:367-74.

29 Tepperman BL, Brown JF, Whittle BJ. Nitric oxide synthase induction and intestinal epithelial cell viability in rats. $A m \mathcal{F}$ Physiol 1993;265:G214-18.

30 Stables R, Campbell CJ, Clayton NM, et al. Gastric anti-secretory, mucosal protective, anti-pepsin and antiHelicobacter properties of ranitidine bismuth citrate. Aliment Pharmacol Ther 1993; 7:237-46.

31 Whittle BJ. Nitric oxide - a mediator of inflammation or mucosal defence. Eur f Gastroenterol Hepatol 1997;9:102632.

32 Colville-Nash PR, Qureshi SS, Willis D, et al. Inhibition of inducible nitric oxide synthase by peroxisome proliferatoractivated receptor agonists: correlation with induction of heme oxygenase 1. F Immunol 1998;161:978-84.

33 Hauser GJ, Dayao EK, Wasserloos K, et al. HSP induction inhibits iNOS mRNA expression and attenuates hypoten- sion in endotoxin-challenged rats. Am f Physiol 1996;271: H2529-35.

34 Kleinert H, Wallerath T, Fritz G, et al. Cytokine induction of NO synthase II in human DLD-1 cells: roles of the JAKSTAT, AP-1 and NF-kappaB-signaling pathways. $\mathrm{Br} \mathcal{F}$ Pharmacol 1998;125:193-201.

35 Takeda K, Ishizawa S, Sato M, et al. Identification of a cisacting element that is responsible for cadmium-mediated induction of the human heme oxygenase gene. F Biol Chem 1994;269:22858-67.

36 Lavrovsky Y, Schwartzman ML, Levere RD, et al. Identification of binding sites for transcription factors NF-kappa B and AP-2 in the promoter region of the human heme oxygenase 1 gene. Proc Natl Acad Sci USA 1994;91:5987-91.

37 Weiss G, Werner-Felmayer G, Werner ER, et al. Iron regulates nitric oxide synthase activity by controlling nuclear transcription. f Exp Med 1994;180:969-76.

38 White KA, Marletta MA. Nitric oxide synthase is a cytochrome P-450 type hemoprotein. Biochemistry 1992; 31:6627-31

39 McMillan K, Bredt DS, Hirsch DJ, et al. Cloned, expressed rat cerebellar nitric oxide synthase contains stoichiometric mounts of heme, which binds carbon monoxide. Proc Natl Acad Sci USA 1992;89:11141-5.

40 Tian L, Lawrence DA. Metal-induced modulation of nitric oxide production in vitro by murine macrophages: lead, nickel, and cobalt utilize different mechanisms. Toxicol Appl Pharmacol 1996;141:540-7.

41 Demontis MP, Varoni MV, Volpe AR, et al. Role of nitric oxide synthase inhibition in the acute hypertensive response to intracerebroventricular cadmium. Br f Pharmacol 1998;123:129-35.

42 Mittal CK, Harrell WB, Mehta CS. Interaction of heavy metal toxicants with brain constitutive nitric oxide synthase. Mol Cell Biochem 1995;149-150:263-5.

43 Persechini A, McMillan K, Masters BS. Inhibition of nitric oxide synthase activity by $\mathrm{Zn} 2+$ ion. Biochemistry 1995;34: 15091-5.

44 Shen Y, Sangiah S. Na+, K(+)-ATPase, glutathione, and hydroxyl free radicals in cadmium chloride-induced testicular toxicity in mice. Arch Environ Contam Toxicol 1995;29:174-9.

45 Hassoun EA, Stohs SJ. Cadmium-induced production of superoxide anion and nitric oxide, DNA single strand breaks and lactate dehydrogenase leakage in J774A.1 cell cultures. Toxicology 1996;112:219-26.

46 Peterson WL, Ciociola AA, Sykes DL, et al. Ranitidine bismuth citrate plus clarithromycin is effective for healing duodenal ulcers, eradicating $\mathrm{H}$. pylori and reducing ulcer recurrence. RBC H. pylori Study Group. Aliment Pharmacol Ther 1996;10:251-61.

47 Axon AT, Ireland A, Smith MJ, et al. Ranitidine bismuth citrate and clarithromycin twice daily in the eradication of Helicobacter pylori. Aliment Pharmacol Ther 1997;11:81-7.

48 Franco L, Talamini G, Carra G, et al. Expression of COX-1, $\mathrm{COX}-2$, and inducible nitric oxide synthase protein in human gastric antrum with Helicobacter pylori infection. Prostaglandins Other Lipid Mediat 1999;58:9-17.

49 Fu S, Ramanujam KS, Wong A, et al. Increased expression and cellular localization of inducible nitric oxide synthase and cyclooxygenase 2 in Helicobacter pylori gastritis. Gastroenterology 1999;116:1319-29.

50 Pullan RD, Ganesh S, Mani V, et al. Comparison of bismuth citrate and 5-aminosalicylic acid enemas in distal ulcerative colitis: a controlled trial. Gut 1993;34:676-9.

51 Griscavage JM, Rogers NE, Sherman MP, et al. Inducible nitric oxide synthase from a rat alveolar macrophage cell nitric oxide synthase from a rat alveolar macrophage cell
line is inhibited by nitric oxide. F Immunol 1993;151:632937.

52 Colasanti M, Persichini T, Menegazzi M, et al. Induction of nitric oxide synthase mRNA expression. Suppression by exogenous nitric oxide. F Biol Chem 1995;270:26731-3.

53 Matthews JR, Botting CH, Panico M, et al. Inhibition of NF-kappaB DNA binding by nitric oxide. Nucleic Acids Res 1996;24:2236-42.

54 Peng HB, Libby P, Liao JK. Induction and stabilization of I kappa B alpha by nitric oxide mediates inhibition of NF-kappa B. F Biol Chem 1995;270:14214-19.

55 Neuzil J, Stocker R. Free and albumin-bound bilirubin are efficient co-antioxidants for alpha-tocopherol, inhibiting plasma and low density lipoprotein lipid peroxidation. $\mathscr{f}$ Biol Chem 1994;269:16712-19.

56 Willis D, Moore AR, Frederick R, et al. Heme oxygenase: a novel target for the modulation of the inflammatory novel target for the modulation

57 Mosley K, Wembridge DE, Cattell V, et al. Heme oxygenase is induced in nephrotoxic nephritis and hemin, a stimulator of heme oxygenase synthesis, ameliorates disease. Kidney Int 1998;53:672-8.

58 Maines MD, Mayer RD, Ewing JF, et al. Induction of kidney heme oxygenase-1 (HSP32) mRNA and protein by ischemia/reperfusion: possible role of heme as both promotor of tissue damage and regulator of HSP32. F Pharmacol Exp Ther 1993;264:457-62.

59 Otterbein L, Sylvester SL, Choi AM. Hemoglobin provides protection against lethal endotoxemia in rats: the role of
heme oxygenase-1. Am $\mathcal{F}$ Respir Cell Mol Biol 1995;13:595601.

60 Hayashi S, Takamiya R, Yamaguchi T, et al. Induction of heme oxygenase-1 suppresses venular leukocyte adhesion elicited by oxidative stress: role of bilirubin generated by the enzyme. Circ Res 1999;85:663-71. 
61 Mourelle M, Guarner F, Marin J, et al. Heme oxygenase: an endogenous antiinflammatory system that accelerates remission of colitis. Gastroenterology 1997;112:A1046.

62 Barton S, Feakins R, Winrow V, et al. Expression of heat shock protein 32 in increased in ulcerative colitis and shock protein 32 in increased in ulcerative co
Crohn's disease. Gastroenterology 1998;114:A927.

63 Mahida YR, Wu KC, Jewell DP. Respiratory burst activity of intestinal macrophages in normal and inflammatory bowel disease. Gut 1989;30:1362-70.
64 McKenzie SJ, Baker MS, Buffinton GD, et al. Evidence of oxidant-induced injury to epithelial cells during inflammatory bowel disease. 7 Clin Invest 1996;98:136-41.

65 Lih-Brody L, Powell SR, Collier KP, et al. Increased oxidative stress and decreased antioxidant defenses in mucosa of inflammatory bowel disease. Dig Dis Sci 1996;41:2078-86. 66 Grisham MB, Granger DN. Neutrophil-mediated mucosal injury. Role of reactive oxygen metabolites. Dig Dis Sci 1988;33:6-15S.

8th United European Gastroenterology Week

The UEGW abstract book (Gut 2000;47(suppl III)) has again been produced as a CD-ROM and can be found attached to the inside back cover of this issue. 